\title{
ANALISIS IMPLEMENTASI PERDA KABUPATEN BANTUL NO.11 TAHUN 2015 TENTANG PEMENUHAN HAK PENYANDANG DISABILITAS PADA KESEHATAN REPRODUKSI REMAJA DISABILITAS
}

\author{
Heri Puspito ${ }^{1}$ \\ ${ }^{1}$ Fakultas Ilmu Kesehatan, Universitas 'Aisyiyah Yogyakarta \\ Email: puspito.heri@unisayogya.ac.id
}

\begin{abstract}
ABSTRAK
Remaja penyandang disabilitas merupakan kelompok rentan terhadap pelecehan dan kekerasan seksual. Penyandang disabilitas juga makhluk seksual yg perlu diperhatikan kesehatan reproduksinya. Pemda Bantul membuat Perda No.11 tahun 2015 untuk memenuhi hak-hak penyandang disabilitas. Penelitian ini bertujuan memperoleh gambaran implementasi kebijakan, khususnya hak-hak kesehatan reproduksi pada remaja disabilitas SLB Negeri di Kabupaten Bantul. Penelitian ini menggunakan pendekatan kualitatif, pemilihan informan dengan purposive sampling, data dikumpulkan dengan wawancara mendalam, observasi dan studi dokumen. Penelitian di lingkungan Pemerintahan Kab.Bantul, Juni-Juli 2019. Hasil penelitian menunjukkan implementasi Perda Bantul No.11 tahun 2015 belum berjalan baik, upaya pemenuhan hak-hak promotif dan preventif belum dicapai. Adanya pengaruh dari Isi Perda, Karakteristik dan kemampuan pelaksana, disposisi pelaksana, serta kondisi lingkungan menyebabkan implementasi menjadi tidak maksimal. Perlu adanya revisi pasal 29 dan 30, menetapkan juklak dan juknis, mengadakan penandatanganan komitmen pelaksana, meningkatkan keterampilan kespro tenaga kesehatan dan guru, serta pelibatan orangtua dalam Pendidikan kespro.
\end{abstract}

Kata Kunci: Remaja, Penyandang Disabilitas, Hak Kesehatan Reproduksi

\section{ABSTRACT}

Adolescent people with disabilities are vulnerable to sexual harassment and violence. Persons with disabilities are sexual beings who need attention to their reproductive health. The local government of Bantul was made a law No.11 in 2015 to fulfill the rights of persons with disabilities. This study aims to obtain a representation of the implementation of policies, especially reproductive health rights of the adolescent with disability in the Extra-Ordinary School Bantul Regency. This study uses a qualitative approach, the selection of informants by purposive sampling, data collected by in-depth interviews, observation, and study of documents. Research in the Government of Bantul Regency, June-July 2019. The results showed that the implementation of Bantul Bylaw No.11 in 2015 has not been going well, efforts to fulfill promotive and preventive rights have not been achieved. The influence is the contents of the Policy, Characteristics and ability of implementers, disposition of implementers, and environmental conditions cause an 
implementation to be not optimal. Revisions to articles 29 and 30 are needed, establishing operational and technical guidelines, signing the commitment of implementers, increasing the health skills of health workers and teachers, and involving parents in reproductive health education.

\section{Keywords : Adolescent, Pearson with Disabilities, Reproductive Health Rights}

\section{LATAR BELAKANG}

Indonesia mengambil langkah meratifikasi UN CRPD (United Nations Convention on the Rights of Persons with Disabilities) oleh Dewan Perwakilan Rakyat Republik Indonesia (DPR RI) pada bulan November 2011 menjadi Undang-undang Nomor 19 tahun 2011 Lembaran Negara Republik Indonesia Tahun 2011 Nomor 107 tentang Ratifikasi Konvensi Internasional Hak-hak Penyandang Disabilitas sebagai upaya pemajuan, penghormatan, pemenuhan dan perlindungan hak-hak kaum disabilitas di seluruh Indonesia, dalam memperkuat komitmen untuk memajukan hak asasi dan untuk menjamin akses pelayanan kesehatan yang sensitif gender, termasuk rehabilitasi kesehatan bagi disabilitas.(RI, 1997)

Masih ada diskriminasi terkait hak-hak reproduksi terutama bagi penyandang disabilitas, sebagian besar difabel mendapatkan akses informasi yang minim tentang kesehatan reproduksi dan seksualitas.(Fauzi, 2017; Nopiah, 2016) Hal ini disebabkan karena minimnya akses pelayanan kesehatan meliputi: konseling, pembinaan, dan bimbingan, serta lemahnya penguasaan teknik komunikasi petugas kesehatan dalam melakukan sosialisasi pelayanan terutama bagi difabel tunarungu dan tuna grahita.(Farisa, Deliana, \& Hendriyani, 2013; Petronela, 2018) Penyandang disabilitas sangat sulit dan minim dalam mendapatkan akses pelayanan kesehatan meliputi, konseling masalah kesehatan reproduksi, konseling reproduksi seputar mitos dan fakta kesehatan reproduksi, advokasi dan konselor sebaya yang membuat nyaman dalam konseling.(Fauzi, 2017; Friedman \& Owen, 2017; Nguyen, Liamputtong, Horey, \& Monfries, 2018) Pemerintah kurang memperhatikan difabel, terbukti dalam survey dan wawancara pada kepala bagian ketahanan remaja, belum ada anggaran untuk program kesehatan reproduksi untuk remaja dengan disabilitas.(Didik, 2017)

Berdasarkan undang-undang nasional tersebut diatas Yogyakarta telah memiliki perda tentang Perlindungan dan Pemenuhan Hak-hak Penyandang Disabilitas No. 4 tahun 2012. Selain itu 3 kabupaten telah memiliki perda untuk melindungi hak-hak disabilitas diantaranya kabupaten Kulon Progo dengan Perda No.3 tahun 2016, Kabupaten Gunungkidul dengan perda No. 9 tahun 2016, kabupaten Bantul dengan perda No.11 tahun 2015. Sedangkan kabupaten Sleman masih dalam proses pengesahan begitu juga dengan kota madya.

Hasil penelitian pada aspek kognitif remaja tunagrahita menunjukkan bahwa perilaku seksual memiliki tingkat perilaku seksual bebas kategori sedang $78 \%$, sedangkan sebanyak $48 \%$ remaja tuna grahita menganggap berpelukan di tempat umum adalah hal yang wajar. Sedangkan aspek afektif menunjukkan perilaku seks bebas sebanyak $14 \%$ responden remaja tuna grahita membenarkan hubungan seksual boleh dilakukan remaja sebagai wujud rasa cinta yang tulus dari pasangan dan $36 \%$ menganggap bahwa berpelukan sambil memegang payudara boleh dilakukan oleh remaja terhadap pacarnya karena mereka menganggap bahwa hal itu bukan merupakan perilaku seks bebas. (Utami, 2015) 
Perlu adanya perlakuan khusus bagi penyandang disabilitas karena mereka juga memerlukan informasi dan pendidikan yang tepat untuk kesehatan reproduksinya. Oleh karena itu pentingnya kebijakan kesehatan reproduksi bagi remaja perlu dilakukan kajian untuk menghasilkan peraturan yang layak dan tepat bagi remaja terutama remaja dengan disabilitas.

\section{METODE PENELITIAN}

Penelitian ini menggunakan pendekatan kualitatif dengan rancangan deskriptif eksploratif. Pemilihan informan didasarkan pada keknik purposive sampling dengan memilih langsung informan dari Kabid Hukum Pemda Bantul, Kepala Dinas Sosial P3A Bantul, Kepala / coordinator Kesga Dinas Kesehatan Bantul, 2 Kepala Puskesmas, Kepala sekolah SLB Negeri Bantul, Guru Kespro, Orangtua Siswa dan Siswa SLB. Pengumpulan data dilakukan dengan Indepth Interview (wawancara mendalam), observasi dan dokumen. Wawancara mendalam semi terstruktur dengan menggunakan petunjuk wawancara (interview guide), sedangkan observasi di lapangan untuk melihat fasilitas, alat peraga, dan melihat kondisi serta sikap remaja di sekolah. Studi dokumen terkait Juklak dan Juknis, Struktur organisasi, SOP, panduan dan laporan kegiatan serta Tujuan pokok dan fungsi.(Creswell, n.d., 2009)

Penelitian ini dilakukan di wilayah kantor pemerintahan Kabupaten Bantul yaitu komplek kantor Bupati, Dinas Kesehatan,Dinas sosial, Dinas Pendidikan Provinsi DIY. Sedangkan diinstansi di bawah pemerintahan yaitu di SLB dan Puskesmas. Penelitian dilakukan selama bulan Juni-Juli 2019.

Penelitian ini menggunakan triangulasi sumber data untuk meningkatkan validitas hasil dari penelitian.(Azwar, 2014) Informan triangulasi terdiri dari 2 Kepala Puskesmas, penanggungjawab program Kespro, kepala sekolah, waka kurikulum, guru Kespro, Orangtua Siswa SLB hingga Siswa SLB.

Wawancara mendalam menggali faktor diantaranya: Isi Perda, Karakteristik dan kemampuan pelaksana, disposisi pelaksana, serta kondisi lingkungan dimana faktor-faktor tersebut mempengaruhi implementasi Perda Bantul No.11 tahun 2015 tentang Pemenuhan Hak-hak Penyandang Disabilitas khususnya Kespro remaja disabilitas. Wawancara mendalam dilakukan 45-60 menit yang dilakukan oleh peneliti sendiri. Sebelum wawancara dilakukan, peneliti mengajukan lembar persetujuan kepada informan, bagi yang menolak tidak dikenakan sanksi dan tidak dijadikan informan penelitian. Pengumpulan data wawancara dengan alat recorder, sedangkan untuk observasi dengan bantuan kamera. 
Tabel 1. Informan Penelitian

\begin{tabular}{lccl}
\hline Kode Informan & Jenis Kelamin & $\begin{array}{c}\text { Usia } \\
\text { (tahun) }\end{array}$ & \multicolumn{1}{c}{ Jabatan } \\
\hline KH & Laki-laki & 51 & Kabid.Hukum \\
KDD & Laki-laki & 54 & Kabid.Diksus Dikpora \\
KkDD & Laki-laki & 58 & Kasi.Kurikulum \& Peserta Didik \\
KDS & Laki-laki & 50 & Kepala Dinas Sosial \\
KKDS & Perempuan & 37 & Kabid.Kesga Dinas Kesehatan \\
Prom & Perempuan & 33 & sie. Promkes \\
KKp & Perempuan & 56 & Koordinator Kespro \\
KKp & Perempuan & 45 & Koordinator kespro \\
Kps & Laki-laki & 36 & Kepala Puskesmas \\
Wak & Perempuan & 50 & Waka kurikulum SLB \\
GKs & Perempuan & 50 & Guru Kespro \\
GKs & Perempuan & 50 & Guru kespro \\
Keps & Perempuan & 54 & Kepala Sekolah SLB \\
Wak & Permepuan & 47 & Waka kurikulum SLB \\
Ot & Perempuan & 42 & Orangtua siswa \\
Ot & Perempuan & 47 & Orangtua siswa \\
S & Perempuan & 18 & Siswa \\
S & Laki-laki & 23 & Siswa \\
\hline Ket & & &
\end{tabular}

Keterangan :

Kabid : Kepala Bidang

Diksus : Pendidikan Khusus

Kesga : Kesehatan Keluarga

Kasi : Kepala Seksi

Kespro : Kesehatan Reproduksi

HASIL DAN PEMBAHASAN

Berikut Ini merupakan cuplikan hasil wawancara dengan Informan:

Table 2 Kutipan Wawancara Analisis Implementasi dalam Upaya Pemenuhan Hak Kesehatan Reproduksi Remaja Disabilitas

$\begin{array}{lll}\text { Tema } & \text { Sub Tema } & \text { Kutipan Terpilih }\end{array}$

Isi Kebijakan

Manfaat dan Pelaksana

Norma-norma dan pola hubungan "sebenarnya dalam tataran pelaksanaannya harus terimplementasi kedalam semua layanan pemerintah"

"ada pelaksanaan jamsus terpadu terkait pelayanan kesehatan dan alat bantu kesehatan secara umum, tidak fokus ke Kespro"

"Belum ada Juklak dan Juknisnya"

Karakteristik dan Kemampuan Pelaksana

"Puskesmas tingkat kehadiran. Tingkat kehadiran remaja di Puskesmas rendah, 
sehingga harus jemput bola."

Cakupan Wilayah

Disposisi Pelaksana

Komitmen

Kesesuain Tugas
"Kalau terkait cakupan wilayah Alhamdulillah semua bisa kami jangkau walaupun medan di sini berbeda dengan yang dibawah (Pkm terletak di daerah perbukitan)" "disini belum ada penandatanganan komitmen selama ini bekerjanya di sini tidak ada yang malas-malas, kalau di sini ya dituntut untuk cekatan."

"justru karna mereka itu guru umum (SLB), supaya kompeten ya ada pelatihan itu.

dikatakan kompeten tidak harus guru-guru itu berbasis kesehatan."

\section{Karakteristik Informan Penelitian}

Penelitian yang dilakukan di Organisasi Perangkat Daerah (OPD) Bantul ini terdiri dari 18 informan yang berusia antara 27 tahun hingga 45 tahun. Jenis kelamin perempuan sebanyak 12 orang sedangkan lai-laki sebanyak 6 orang. Informan utama memiliki jabatan di masing-masing instansi diantaranya sebagai Kabid Hukum, Kepala Dinas Sosial Pemberdayaan Perempuan dan Perlindungan Anak (Dinsos P3A), Koordinator Kesga Dinkes Bantul, sie Promosi Kesehatan Dinkes. Selain itu, juga melibatkan Kepala Bidang Pendidikan Khusus, Kabid Kurikulum Dinas DIKPORA DI.Yogyakarta. Informan triangulasi terdiri dari Kepala Puskesmas, Penanggungjawab program kespro, Kepala sekolah, guru kespro, orangtua siswa SLB, dan Siswa SLB.

\section{Implementasi Upaya Promotif dan Preventif Kesehatan Reproduksi}

OPD kabupaten Bantul dalam memenuhi hak kesehatan reproduksi remaja penyandang disabilitas bidang promotif dan preventi belum berjalan sesuai darapan. Informasi terkait kesehatan reproduksi dan seksualitas belum didapatkan remaja di SLB dengan maksimal, padahal mereka membutuhkan lebih dari remaja yang normal. Puskesmas dan Dinas Kesehatan masih berfokus kepada remaja yang normal, selain itu dinas sosial berfokus pada penjaminan kesehatan gratis dan pemenuhan kesejahteraan sosial penyandang disabilitas.

Berdasarkan pengakuan siswa, di sekolah mereka merasa belum menerima pelajaran kesehatan reproduksi secara maksimal yang berasal dari instansi pemerintah, mereka mengaku mendapatkan pengetahuan kespro dari mahasiswa dan dosen, itu pun sebagai obyek penelitian. Selain itu, orangtua siswa merasa tidak dilibatkan oleh sekolah untuk memperoleh materi dan pendidikan kesehatan reproduksi yang berguna untuk mendidik anaknya.

"Selama ini saya baru mendapatkan materi kesehatan reproduksi 2-3 kali di pelajaran IPA terpadu. (siswa SLB)"

Berdasarkan analisis peneliti, Dinas Kesehatan, dan Dinas Sosial belum berfokus pada kesehatan reproduksi remaja disabilitas. Mereka berpedoman pada tren isu 
kesehatan dan program dari pemerintah pusat, bukan pada Perda Bantul No. 11 tahun 2015 tentang Pemenuhan Hak-hak Penyandang Disabilitas.

\section{Faktor yang Mempengaruhi Implementasi Perda}

\section{a. Isi Perda}

Ada perbedaan antara isi kebijakan dengan fakta dilapangan. Di dalam Perda dinyatakan, bahwasanya OPD yang memiliki tugas pokok fungsi di bidang pendidikan berkewajiban menyediakan informasi pelayanan umum tentang sistem pendidikan inklusif bagi penyandang disabilitas dan keluarganya. Fakta dilapangan, orang tua penyandang disabilitas belum dilibatkan sepenuhnya dalam pendidikan putera-puterinya. Berikut kutipan wawancara dari orangtua siswa SLB,

"Kalau kegiatan di sekolah mengenai pembelajaran kesehatan reproduksi kami jarang dilibatkan sama guru-gurunya. Kami hanya menunggu di luar kelas. Dulu itu hanya sekali pas awal masuk sekolah.(orang tua siswa SLB)"

Selain itu di dalam Perda tersebut tampak perbedaan antara Perda Bantul pada pasal 29 dan 30 terkait kesehatan reproduksi dengan Perda DIY No. 4 tahun 2012 tentang Pemenuhan Hak-hak Penyandang Disabilitas. Di dalam Perda DIY terdapat pasal bagaimana upaya promotive dan preventif dilakukan, namun di Perda Bantul justru malah dihapuskan. Hal ini tentunya tidak sesuai dengan turunan Perda DIY tersebut. Sehingga, Kespro Disabilitas menjadi terabaikan.

Penelitian yang dilakukan oleh Octaviani dengan judul Penerapan Governance dalam implementasi Perda Penyandang Disabilitas di Kota Denpasar diperoleh kesimpulan bahwa isi kebijakan diperlukan untuk bisa menghasilkan programprogram yang dapat dikembangkan oleh pemerintah yang disesuaikan dengan kebutuhan penyandang disabilitas. Hal ini disebabkan karena mereka lebih senang melakukan usaha mandiri. Pelaksanaan perda harus menghasilkan manfaat yang diterima dan mengakomodir mpenyandang disabilitas berdasarkan program-program yang dijalankan. Tidak cukup sampai disitu, manfaat yang diterima penyandang disabilitas harus dapat memberikan dampak perubahan bagi kehidupan penyandang disabilitas.(Octaviani, Erviantono, \& Purnamaningsih, 2015)

Implementasi kebijakan menurut Erdward III, adalah suatu proses yang sangat penting sebab berjalannya suatu kebijakan dengan baik diimbangi dengan persiapan dan perencanaan yang baik, maka dengan itu harapan dan tujuan yang sudah disusun dapat dicapai. (George C. Edward III, 1980) Menurut Grindle Keberhasilan dalam mengimplementasikan kebijakan tergantung juga pada isi kebijakan dan lingkungan implementasi. Kepentingan dari pemerintah adalah perwujudan nyata dari implementasi kebijakan yang dipengaruhi oleh adanya program tersebut.(Wahab, 2007; Winarno, 2012)

\section{b. Karakteristik dan Kemampuan Pelaksana}

Hasil yang lain menunjukkan bahwa dalam implementasi Perda Bantul tersebut masing-masing implementor memiliki struktur birokrasi dan norma-norma yang dianut menurut lokasi dimana mereka bekerja. Keadaan tersebut menjadikan pola hubungan yang terjadi selama birokrasi kurang baik, karena mereka masih berfokus pada program kerjanya masing-masing serta fokus pada tujuan pokok dan fungsi masing-masing organisasi. Misalnya saja puskesmas belum melibatkan siswa-siswi SLB dalam program PKPR karena puskesmas menganggap daya tangkap 
penyandang disabilitas rendah, padahal tidak semua penyandang disabilitas di SLB memiliki daya tangkap rendah.

Berbeda dengan pendapat Kabid.Dikpora DI.Yogyakarta, menurut beliau penyampaian tentang pendidikan kespro remaja kepada siswa-siswi SLB tidak harus dari bidang Kesehatan, karena guru-guru SLB mempunyai kompetensi untuk berkomunikasi dengan penyandang disabilitas dari pada petugas kesehatan. Guruguru tersebut tinggal diberikan keterampilan dan kompetensi terkait pengetahuan Kespro. Pemikiran seperti inilah yang membuat pola hubungan menjadi baik dalam bekerjasama dengan instansi lain dalam memenuhi hak-hak kespro remaja penyandang disbailitas.

Hasil Penelitian Rahmasari et.al tentang Precede and Proceed Model on Determinants of Teacher's Role in the Provision of Reproductive Health Education for Students with Mild Mental Retardation at School of Disability in Sleman, ada kendala yang dialami guru dalam menyampaikan materi kesehatan reproduksi yang berdampak pada kemampuan dan karateristik pelaksana yaitu (1) Guru mengalami kesulitan menyampaikan materi yang dapat dipahami oleh anak tuna grahita, (2) sulit menentukan pendekatan atau strategi karena siswa berbeda latarbelakang, usia dan level ketunaan berbeda, (3) Keterbatasan SDM yang sudah pelatihan dan mampu memberikan materi Kesehatan Reproduksi, (4) pengetahuan dan pelibatan orang tua masih rendah, (5) pandangan sosial budaya dari masyarakat yang menganggap tabu mengenai pendidikan kesehatan reproduksi. Berbagai pemahaman Guru, dalam memahami tujuan pendidikan kesehatan reproduksi diantaranya: membangun kesadaran terkait pentingnya menjaga kespro, membiasakan diri hidup sehat, melatih kemandirian, bergaul dengan sehat. Dengan demikian, pemahaman dan perspektif guru sangat berpengaruh terhadap pemenuhan hak-hak kesehatan reproduksi. (Rahmasari, Astuti, \& Sulaeman, 2012)

Menurut penelitian Salla "Analisis Kinerja Dinas Kesehatan Kabupaten Mamberamo Tengah Pada Program Kesehatan Ibu dan Anak", menyatakan bahwa petugas yang telah memperoleh pelatihan memiliki kinerja tinggi sebesar 2,9 kali lebih besar dibandingkan dengan petugas yang belum pernah mendapatkan pelatihan. (Salla, 2017) Hal ini sesuai dengan teori Notoatmodjo, bahwa Pelatihan merupakan salah satu bentuk pendidikan, karena dengan pelatihan atau training dapat memberikan pengalaman belajar yang akan merubah perilaku. Pelatihan sangat diperlukan, karena hal ini sebagai proses mengajarkan keahlian atau keterampilan termasuk pengetahuan agar tercipta sikap yang bertanggungjawab sesuai dengan standar kerja.(Notoatmodjo, 2010, 2012)

Menurut Metter dan Horn, kinerja implementasi dipengaruhi oleh ciri yang cocok dan tepat dengan agen pelaksana. Dalam proses implementasi kebijakan, agen pelaksana dituntut untuk disiplin dan taat. Disisi lain juga dibutuhkan implementor yang mempunyai sikap demokratis dan persuasive. Sementara itu ada hal yang penting dalam menentukan implementor, yaitu cakupan wilayah atau luas wilayah.(Subarsono, 2011; Winarno, 2012)

\section{c. Disposisi pelaksana}

Disposisi menyangkut beberapa hal terkait sikap, komitmen dan kesesuaian tugas adalah hal penting menjadi kesuksesan implementasi. Sikap implementor terhadap pemenuhan hak-hak kesehatan reproduksi penyandang disabilitas, dimana 
implementor tidak ada keluhan terkait tugas yang dijalankan, fasilitas yang diberikan dan dana yang ada. Ketika melayani penyandang disabilitas yang periksa di Puskesmas sudah ada SPM pelayanan, petugas sesuai dengan SPM yang berlaku, SPM yang ada tidak hanya untuk penyandang disabilitas namun juga untuk masyarakat umum yang datang memeriksakan diri. Adanya SPM ini tujuannya adalah ramah penyandang disabilitas. Petugas di Puskesmas melaksanakan program dan kegiatan sesuai jadwal dan tugas yang diberikan dan dikerjakan sesuai waktunya. Keseluruhan pelayanan tersebut bersumber dari pemerintah pusat, karena merupakan program dari kementrian kesehatan.

Berdasarkan hasil observasi, petugas belum memiliki tujuan pokok dan fungsi (Tupoksi) untuk pelaksanaan Perda Bantul No.11 Tahun 2015 untuk memenuhi hakhak penyandang disabilitas, sehingga mereka tidak memiliki pedoman untuk mengimplementasikan Perda tersebut. Karena tidak ada tupoksi dan uraian tugas yang jelas dan kekurangan staf, maka petugas banyak yang merangkap tugas. Oleh karena hal itu, berdampak pada pendidikan kesehatan reproduksi di sekolah. Di SLB pendidikan kespro belum berjalan maksimal, karena orangtua belum dilibatkan oleh sekolah dan sekolah cenderung tidak mengulangi materi kesehatan reproduksi kepada siswa-siswinya. Sikap positif terlihat pada guru SLB yang mengajar Kesehatan Reproduksi (Kespro). Guru-guru sudah membedakan antara penyandang daksa, grahita, netra dan wicara ketika diajarkan materi kesehatan reproduksi. Dan guru sudah mengulang-ngulang materinya pada siswa penyandang daksa. Implementor belum menandatangani kesepakatan komitmen untuk memenuhi hak-hak penyandang disabilitas.

"penyampaianya berjenjang, dan dibedakan berdasarkan usia, tuna daksa, grahita, rungu, wicara, agar maksimal. (Guru SLB)"

Hasil penelitian Fahmawati menunjukkan bahwa sikap pelaksana program kurang responsif terhadap laporan peserta terdampak program (penilaian peringkat kinerja perusahaan pengelola lingkungan hidup), sehingga tujuan kebijakan menjadi terhalang. (Fahmawati \& Purnaweni, 2016).

Menurut Edwards III karakter yang wajib dimiliki pelaksana yaitu sifat jujur, karena sifat ini akan memberikan arah kepada implementor berada dalam arah program yang telah ditetapkan pada petunjuk pelaksanaan program. Komitmen yang tinggi dan kejujuran yang dijunjung akan berdampak pada antusiasme implementor dalam melaksanakan setiap tahap program dengan konsisten. Ada sikap yang lain yang pelu dimiliki implementor, yaitu sikap demokratis. Sikap demokratis dapat membawa dampak positif yaitu memberikan kesan baik antara implementor dan kebijakan dengan kelompok sasaran. Sikap demokratis juga akan menurunkan penolakan atau resistensi dari masyarakat terhadap pelaksana dan kebijakan atau program.(George C. Edward III, 1980) Pendapat dari teori Van Meter dan Horn. Kognisi atau pemahaman terhadap suatu kebijakan akan mempengaruhi kemauan implementor.(Donald S. Van Meter and Carl E. Van Horn, 1975)

\section{d. Kondisi lingkungan}

Orang tua mengusulkan bahwa perlu adanya pelibatan orang tua secara konsisten dalam pembelajaran kesehatan reproduksi sehingga orang tua bisa tahu bagaimana 
mendidik kesehatan reproduksi anaknya. Bupati sebenarnya sangat perduli terhadap masalah kesehatan reproduksi, sebab anggaran dan program yang diajukan selalu disetujui, selain itu Bupati juga turut hadir dalam acara ketika diundang. Selain pemerintah daerah, pemerintah provinsi turut mendukung pendidikan di SLB, dengan dukungan berupa penarikan sejumlah guru di SLB Swasta ke SLB negeri untuk mencukupi jumlah tenaga pendidik di SLB. Selain penambahan guru di SLB Negeri, juga diberikan pelatihan kesehatan reproduksi gratis setiap tahun untuk guru-guru SLB. Hal ini menunjukkan dukungan dari lingkungan pemerintah sangat mendukung bagi tercapainya pemenuhan hak-hak kespro remaja disabilitas.

Menurut informan masih ada sebagian masyarakat yang menganggap bahwa masalah seksual belum patut diajarkan kepada anak-anak karena menurut mereka belum waktunya. Orangtua dalam penelitian ini sangat mendukung program pendidikan kesehatan reproduksi sebab orangtua merasa tidak mampu bagaimana cara mendidik anak-anaknya dan menyelesaikan masalah kesehatan reproduksinya.

Hasil penelitian Octaviani menunjukkan bahwa dukungan dan perhatian yang besar dari lingkungan masyarakat dan sekitar sangat berpengaruh dan berdampak besar pada pelaksanaan Perda Provinsi Bali No.9 Tahun 2015 tentang Penyandang Disabilitas.(Octaviani et al., 2015) Sedangkan hasil penelitian Petronela, tentang pemenuhan informasi dan hak kesehatan reproduksi perempuan disabilitas di Kota Semarang menemui hambatan berupa kurangnya partisipasi masyarakat dalam memberikan dukungan pada penyandang disabilitas yang berada di lingkungan masyarakat.(Petronela, 2018) Menurut hasil penelitian Setiawan dan Pudjianto tentang Pemenuhan Hak Penyandang Disabilitas Berat, ekonomi sangat mempengaruhi terhadap pemenuhan hak Penyandang Disabilitas Berat, hal ini dikarenakan semakin tinggi pendapatan seseorang atau pemasukan keluarga akan berdampak pada tercukupinya kebutuhan penyandang disabilitas berat dan sebaliknya.(Setiawan \& Pudjianto, 2017)

Lingkungan eksternal turut mendorong keberhasilan implementasi kebijakan dianataranya adalah lingkungan sosial, ekonomi dan politik. Ketiga lingkungan tersebut apabila tidak kondusif dapat menjadi sumber masalah yang mengakibatkan kegagalan kinerja implementasi kebijakan. Oleh karena itu, implementasi kebijakan mensyaratkan kondisi lingkungan eksternal yang kondusif.(Donald S. Van Meter and Carl E. Van Horn, 1975)

\section{SIMPULAN DAN SARAN Simpulan}

Upaya promotif dan preventif terkait kesehatan reproduksi bagi remaja penyandang disabilitas belum dilaksanakan dengan maksimal oleh OPD. Kegiatan berupa penyuluhan dan seks education yang dilakukan oleh tenaga kesehatan diimplementasikan ke SLB. isi kebijakan di bagian kesehatan masih bersifat umum, belum ada pasal terkait kesehatan reproduksi dan kegiatan upaya promotif, preventif seperti yang diharuskan ada Undangundang Konvensi Disabilitas. Karakteristik dan Kemampuan Implementor kurang baik karena masih berfokus pada program kerja masing-masing. Belum adanya penandatanganan komitmen Bersama. Kondisi lingkungan (ekonomi, sosial, budaya dan pendidikan) mendukung dalam implementasi Perda Bantul No.11 Tahun 2015. 


\section{Saran}

Merubah perilaku remaja disabilitas melalui SLB tidak hanya melalui penyuluhan, tetapi juga praktek secara langsung yang dilakukan berulang-ulang. Perlu dilakukan revisi pasal 29 dan 30 Perda Bantul No.11 Tahun 2015 tentang Pemenuhan Hak-hak Penyandang Disabilitas yang mengacu pada UU No. 19 tahun 2011 tentang Konvensi Hak-hak Penyandang Disabilitas, PP No. 61 tahun 2014 tentang Kesehatan Reproduksi, UU No.35 tahun 2014 Perubahan UU No.23 tahun 2002 tentang Perlindungan Anak, UU No.7 tahun 1984 tentang Perlindungan Perempuan, selain itu menetapkan Tujuan Pokok dan Fungsi. Pelatihan tenaga kesehatan bahasa isyarat. Penetapan struktur organisasi, pembuatan uraian tugas, juklak-juknis, serta menyamakan persepsi terhadap tugas dan kewajiban implementor. Pembuatan kesepakatan dan penandatanganan komitmen implementor bahwa hak-hak penyandang disabilitas harus dipenuhi.

\section{DAFTAR PUSTAKA}

Azwar, S. (2014). Metode Penelitian. Yogyakarta: Pustaka Pelajar.

Creswell, J. W. (n.d.). Research design.

Creswell, J. W. (2009). Research Design Qualitative, Quantitative, and Mixed Methods Approaches (3rd.edition) (3rd ed.). United State: SAGE Publication.

Didik. (2017). wawancara Kasubid Bidang Ketahanan Remaja BKKBN Provinsi D.I Yogyakarta.

Donald S. Van Meter and Carl E. Van Horn. (1975). Administration \& Society The Policy Implementation Process: A Conceptual Frame-work. United State: Sage Journals.

Fahmawati, R., \& Purnaweni, H. (2016). Implementasi Kebijakan Program Penilaian Peringkat Kinerja Perusahaan Dalam Pengelolaan Lingkungan Hidup (PROPER) di Kota Semarang. FISIP UNDIP.

Farisa, T. D., Deliana, S. M., \& Hendriyani, R. (2013). Faktor-faktor Penyebab Perilaku Seksial Menyimpang Pada Remaja Tunagrahita SLB N Semarang. Psikologi UNNES, $13,18$.

Fauzi, M. F. M. (2017). Implementasi United Nations Convention on The Rights of Persons with Disabilities (UNCRPD) Terhadap Pemenuhan Hak AKSESBILITAS Bagi Penyandang Disabilitas di Indonesia (Studi Kasusu di Kota Makassar).

Friedman, C., \& Owen, A. L. (2017). Sexual health in the community: Services for people with intellectual and developmental disabilities. Disability and Health Journal. https://doi.org/10.1016/j.dhjo.2017.02.008

George C. Edward III. (1980). Implementing Public Policy,. Washington: Congressional Quarterly Press.

Nguyen, T. T. A., Liamputtong, P., Horey, D., \& Monfries, M. (2018). Knowledge of Sexuality and Reproductive Health of People with Physical Disabilities in Vietnam. Sexuality and Disability, 36(1). https://doi.org/10.1007/s11195-017-9515-7

Nopiah, R. (2016). Evaluasi Pelaksanaan Perda Disabilitas Bantul. Retrieved November 22, 2018, from 12 November website: http://mpm.muhammadiyah.or.id/index.php/2016/11/12/evaluasi-pelaksanaan-perdadisabilitas-bantul/

Notoatmodjo, S. (2010). Ilmu Perilaku Kesehatan. Jakarta: Rineka Cipta.

Notoatmodjo, S. (2012). Promosi Kesehatan dan Perilaku Kesehatan. Jakarta: Rineka Cipta. 
Octaviani, N. P. E., Erviantono, T., \& Purnamaningsih, P. E. (2015). Penerapan Governance dalam Implementasi Perda Penyandang Disabilitas di Kota Denpasar ( Studi Kasus Implementasi Peraturan Daerah Provinsi Bali Nomor 9 Tahun 2015 Tentang Perlindungan Dan Pemenuhan Hak Penyandang Disabilitas ). Fisipol Univ. Udayana, 1-8.

Petronela, M. (2018). Pemenuhan Hak Atas Informasi dan Hak Kesehatan Reproduksi Bagi Perempuan Penyandang Disabilitas di Kota Semarang. Hukum Kesehatan.

Rahmasari, P., Astuti, I. D., \& Sulaeman, E. S. (2012). Teacher's Role In Reproductive Health Education for Reproductive Health of Students Teenage with Mild Mentally Retarded in Extraordinary School Sleman Yogyakarta.

RI. Undang-undang Republik Indonesia No. 4 Tahun 1997 tentang Penyandang Cacat. , $1997 \S(1997)$.

SALLA, S. T. (2017). Analisis Kinerja Dinas Kesehatan Kabupaten Mamberamo Tengah Pada Program Kesehatan Ibu Dan Anak. 6(2), 112-117.

Setiawan, H. H., \& Pudjianto, B. (2017). Pemenuhan Hak Penyandang Disabilitas Berat. PKS, 16(SEPTEMBER 2017), 311-322.

Subarsono, A. (2011). Analisis Kebijakan Publik (konsep, teori dan aplikasi). Yogyakarta: Pustaka Pelajar.

Utami, D. R. (2015). Identifikasi Perilaku Seksual Bebas Pada Remaja Tunagrahita di SLB N 1 BANTUL. Universitas 'Aisyiyah Yogyakarta.

Wahab, S. A. (2007). Analisis Kebijaksanaan: Dari Formulasi ke Implementasi Kebijaksanaan Negara. In Bumi Aksara. Jakarta: Bumi Aksara.

Winarno, B. (2012). Kebijakan Publik Teori, Proses dan Studi Kasus (pertama; Redaksi CAPS, Ed.). Yogyakarta: CAPS. 